\title{
NILAI PERUSAHAAN DAN FAKTOR-FAKTORNYA: PENDEKATAN TOBINS Q PADA PERSUAHAAN MANUFAKTUR DI BURSA EFEK INDONESIA
}

\author{
M. Nasir ${ }^{1)}$ \\ ${ }^{1)}$ Fakultas Ekonomi, Universitas Negeri Medan \\ email: nasir_muhammad11@yahoo.co.id
}

\begin{abstract}
Abstrak
Pada tahun 2016 Indonesia dihadapkan dengan era perdagangan bebas di Asia Tenggara yang dinamakan dengan Masyarakat Eknomi ASEAN (MEA). Oleh karena itu, perusahaan berlomba-lomba menarik perhatian investor maupun kreditor agar tertarik untuk menanamkan modalnya diperusahaan. Salah satu faktor penilai investor dan kreditor dalam menanamkan modalnya diperusahaan adalah kinerja perusahaan. Dimana dengan adanya kinerja yang baik tersebut diharapkan memperoleh pengembalian yang baik juga. Penelitian ini dilakukan pada perusahaan industri yang terdaftar di Bursa Efek Indonesia periode 2014. Teknik pengumpulan sampel dengan menggunakan purposive sampling. Teknik pengujian hipotesis dengan menggunakan regresi linear berganda. Sebelum dilakukan pengujian hipotesis, dilakukan terlebih dahulu pengujian asumsi klasik. Hasil penelitian ini menunjukkan hanya variabel struktur modal yang berpengaruh signifikan terhadap nilai perusahaan. Tetapi secara umum seluruh variabel berpengaruh signifikan terhadap nilai perusahaan. Profitabilitas pada penelitian ini tidak dapat dijadikan sebagai variabel moderating
\end{abstract}

Kata Kunci : Nilai Perusahaan, Tata Kelola Perusahaan, Kinerja Lingkungan, Struktur Modal, Kualitas Audit, Profitabilitas . 


\section{PENDAHULUAN}

Pada era Masyarakat Ekonomi Asean (MEA) ini setiap negara yang bergabung dalam ASEAN bebas melakukan perdagangan sehingga tenaga kerja akan secara bebas keluar masuk ke suatu negara maupun perusahaan multinasional yang akan berlomba untuk memperluas wilayah produksi dan juga pemasarannya.

Disamping itu, dalam mempertahankan persaingan dan tetap bertahan dipasar, perusahaan mempunyai dua tujuan utama yang harus dicapai yaitu tujuan jangka pendek dan tujuan jangka panjang. Dimana tujuan jangka pendek perusahaan yaitu memaksimalkan profit perusahaan dan jangka panjang mensejahterakan pemilik perusahaan. Dalam mencapai tujuan tersebut, diperlukan suatu keunggulan yang lebih dibandingkan dengan perusahaan lain yang dinamakan keunggulan kompetitif. Dengan adanya keunggulan kompetitif diharapkan perusahaan dapat bertahan serta bersaing dengan perusahaan lainnya.

Adanya MEA diharapkan perusahaan dapat mencapai tujuan jangka pendek melebihi target yang ditetapkan dengan memperluas daerah pemasaran. Untuk meningkatkan produksi dan memperluas pemasaran, perusahaan membutuhkan dana yang cukup besar sumber dana dapat diperoleh dari internal perusahaan dan eksternal perusahaan. Sumber dana yang berasal dari internal perusahaan yaitu dari laba yang tidak dibagikan kepada pemilik saham (laba ditahan). Sedangkan sumber pendanaan yang yang berasal dari eksternal perusahaan berasal dari hutang dan penjualan saham. Pendanaan yang berasal dari laba sulit diperoleh dikarenakan prosesnya lama dan jumlahnya sangat terbatas. Sumber pendanaan yang berasal dari hutang sangatl berisiko. Oleh sebab itu, sumber dana yang mempunyai tingkat risiko yang kecil yaitu berasal dari penjualan saham.

Untuk memenuhi kebutuhan dana yang berasal dari penjualan saham tidaklah mudah. Hal ini berkaitan dengan kepercayaan investor terhadap perusahaan yang tercermin pada nilai perusahaan. Semakin tinggi nilai suatu perusahaan maka semakin tinggi keinginan investor untuk menanamkan modalnya diperusahaan.

Nilai perusahaan menunjukkan apa yang telah dicapai perusahaan sehingga tercermin dari kepercayaan investor untuk menanamkan modalnya diperusahaan. Salah satu cara menilai
NIAGAWAN Vol 8 No 3 November 2019

kepercayaan investor yaitu dengan meningkatnya harga saham. Dimana dengan adanya peningkatan nilai saham menunjukkan investor berlomba-lomba menanamkan modalnya diperusahaan dengan membeli saham.

Salah satu yang perlu dipertimbangkan perusahaan dimana investor dalam menilai perusahaan yaitu kinerja perusahaan. Kinerja perusahaan ini dapat dilihat dari laporan keuangan yang dipublikasikan. Oleh sebab itu, perusahaan harus secara maksimal melaksanakan kegiatan operasi perusahaan sehingga kinerja perusahaan akan meningkat yang nantinya dipublikasikan pada laporan keuangan. Perusahaan harus dapat memperhatikan aspek-aspek yang dapat mencerminkan kinerja perusahaan pada laporan keuangan.

Salah satu contoh perusahaan yang memiliki nilai perusahaan yang tinggi yaitu PT Freeport Indonesia. PT Freeport Indonesia merupakan salah satu perusahaan pertambangan terbesar dan memiliki asset dan profit yang cukup besar. Seperti pada tahun 2012 PT Freeport Indonesia membayar dividen kepada pemegang saham mencapai US\$ 2,19 miliar (Rp 24,9 triliun) atau sekitar 84 persen dari labanya buat para pemegang saham di bursa saham Wall Street, New York (http://www.kompasiana.com). Hal ini menarik investor untuk mengembangkan perusahaan dan berlomba-lomba untuk menanamkan modalnya diperusahaan. Walaupun memiliki nilai yang baik dimata investor, PT Freeport juga melakukan pelanggaran terhadap lingkungan. Pelanggaran yang dilakukannya yaitu matinya Sungai Aijkwa, Aghawagon dan Otomona, tumpukan batuan limbah tambang dan tailing yang jika ditotal mencapai 840.000 ton dan matinya ekosistem di sekitar lokasi pertambangan (http://www.kompasiana.com/). Jadi jika kita lihat PT Freeport Indonesia hanya mementingkan nilai perusahaan tetapi tidak memperhatikan dampak kegiatan operasinya terhadap lingkungan. Sehingga perlu dilihat faktor-faktor apa saja yang mempengaruhi suatu perusahaan dalam meningkatkan nilai perusahaan tanpa merugikan lingkungan, Adapun faktor-faktor yang mempengaruhi nilai perusahaan yaitu tata kelola perusahaan, kinerja lingkungan, struktur modal, kualitas audit, dan profitabilitas sebagai variabel moderating.

Sehingga dengan adanya faktor-faktor tersebut diatas, penelitian ini dapat memberikan 
gambaran kepada perusahaan mengenai aspekaspek yang mempengaruhi nilai perusahaan. Memperhitungkan aspek tersebut diharapkan dapat meningkatkan nilai perusahaan pada akhirnya investor tertarik menanamkan modalnya diperusahaan.

Aspek tersebut tidak selamanya menjadi faktor penentu bagi kinerja dan nilai perusahaan yang baik. Hal ini seperti yang terjadi pada kasus ENRON yang memanipulasi laporan keuangan sehingga investor merasa dibohongi atas laporan keuangan yang dipublikasikan (http://finance.laws.com/enron-scandal-

summary). Contoh kasus yang terjadi di Indonesia yaitu pada perusahaan PT Kimia Farma Tbk yang memanipulasi berupa oversated dalam menilai persediaan barang jadi serta overstated dalam mencatat nilai penjualan. Sehingga laba yang dilaporkan mengalami overstated untuk tahun yang berakhir 31 Desember 2001 (Bapepam, 2002). Selain itu, usaha untuk meningkatkan nilai perusahaan juga terjadi pada pada PT Indofarma Tbk dan PT Lippo TBK yang memanipulasi nilai buku laporan keuangan perusahaan sehingga investor kehilangan kepercayaan.

Oleh sebab itu perlu diperhatikan lebih lanjut aspek-aspek yang mempengaruhi nilai perusahaan. Hal ini bertujuan agar kepercayaan public terhadap perusahaan meningkat yang pada akhirnya nilai perusahaan juga akan meningkat.

\section{TINJAUAN PUSTAKA}

\section{Teori Stakeholders}

Berdasarkan teori stakeholder dapat dilihat bahwa perusahaan disamping tidak dapat terpisah dari campur tangan stakeholders dan juga dapat terlepaskan diri lingkungan sosial. Hal ini dikarenakan perusahaan yang lebih menghargai lingkungan hidup akan lebih diperhatikan sebagai perusahaan yang akan perduli dengan keberlanjutan perusahaan dan kesejahteraan stakeholders.

\section{Nilai Perusahaan}

Nilai perusahaan menunjukkan persepsi investor terhadap perusahaan terbuka, yang sering dikaitkan dengan harga saham (Sujoko dan Soebiantoro, 2007). Harga saham yang tinggi mengindikasikan nilai perusahaan yang tinggi. Nilai perusahaan yang tinggi akan membuat pasar percaya tidak hanya pada kinerja
NIAGAWAN Vol 8 No 3 November 2019 perusahaan saat ini namun juga prospek perusahaan di masa depan (Hardiyanti, 2012).

\section{Tata Kelola Perusahaan}

Tata kelola perusahaan menunjukkan rangkaian proses, kebiasaan, kebijakan, aturan, dan institusi yang memengaruhi pengarahan, pengelolaan, serta pengontrolan suatu perusahaan atau korporasi. Tata kelola perusahaan juga mencakup hubungan antara para pemangku kepentingan (stakeholder) yang terlibat serta tujuan pengelolaan perusahaan.

\section{Kinerja Lingkungan}

Tanggung jawab lingkungan yaitu suatu bentuk aktivitas yang dilakukan perusahaan untuk meningkatkan ekonomi perusahaan sekaligus peningkatan kualitas hidup karyawan beserta keluarganya dan juga kualitas hidup masyarakat sekitar. Menurut Cheng dan Yulius (2011), aktivitas CSR dapat memberikan banyak manfaat, seperti: dapat meningkatkan citra dan daya tarik perusahaan di mata investor serta analis keuangan penjualan, dapat menunjukan brand

positioning, dan dapat meningkatkan penjualan dan market share. Sehingga pada akhirnya juga akan meningkatkan nilai perusahaan dengan adanya tanggung jawab perusahaan terhadap lingkungan.

\section{Struktur Modal}

Struktur modal menunjukkan penggunaan dana yang berasal dari luar perusahaan dalam membiayai aktivitas operasi perusahaan. Struktur modal merupakan kombinasi utang dan ekuitas dalam struktur keuangan jangka panjang perusahaan, tidak seperti rasio utang yang hanya menggambarkan target komposisi utang dan ekuitas dalam jangka panjang pada suatu perusahaan (Arifin, 2005). Struktur modal yang optimal terjadi pada leverage keuangan tingkat tertentu. Leverage keuangan merupakan penggunaan dana, dimana dalam penggunaan dana tersebut perusahaan harus mengeluarkan beban tetap (Martono dan Harjito, 2005:240).

\section{Kualitas Audit}

Kualitas audit menunjukkan bagaimana auditor dapat menemukan kesalahan atas apa yang dilakukan perusahaan selama melakukan kegiatan operasinya. Dengan adanya kualitas audit ini akan memberikan kepercayaan kepada 
Audit berkualitas tinggi berperan sebagai penghalang efektif manajemen laba karena reputasi manajemen akan rusak dan nilai perusahaan akan turun apabila terbukti ada kesalahan pelaporan sehingga diprediksikan manajemen laba lebih banyak terjadi pada perusahaan yang memiliki auditor berkualitas rendah.

\section{Profitabilitas}

Profitabilitas menunjukkan kemampuan perusahaan untuk menghasilkan keuntungan atau laba bagi perusahaan. pada variabel ini menunjukkan bagaimana suatu perusahaan dapat memiliki kinerja yang baik. Semakin baik kinerjanya maka semakin tertarik pula investor untuk menanamkan modalnya diperusahaan. hal ini dikarenakan pengembalian yang akan investor peroleh dari modal yang ia tanamkan di perusahaan.

\section{METODE PENELITIAN}

\section{Pengumpulan}

Jenis data yang digunakan adalah data sekunder yang berasal dari laporan keuangan perusahaan sampel. Maksud dari penelitian ini adalah untuk menguji dan menganalisis variabelvariabel apa saja mempengaruhi nilai perusahaan dan tingkat profitabilitas perusahaan sebagai variabel moderating. Tahun pengamatan pada penelitian ini adalah tahun 2014. Lokasi penelitian ini yaitu pada perusahaan industri yang listing di Bursa Efek Indonesia. Data penelitian diperoleh melalui website resmi Bursa Efek Indonesia yaitu www.idx.co.id. Adapun waktu yang dipakai pada penelitian ini adalah Mei-Desember 2016. Adapun populasi pada penelitian ini adalah perusahaan industri di Bursa Efek Indonesia periode 2014. Teknik pengambilan sampel dengan metode purposive sampling

Teknik-Teknik yang Digunakan

1. Model analisis data yang digunakan untuk menguji hipotesis adalah regresi linier berganda dengan model yang digunakan untuk menguji hipotesis adalah sebagai berikut:

$$
\begin{aligned}
& Y=\alpha_{0}+\alpha_{1} X_{1}+\alpha_{2} X_{2}+\alpha_{3} X_{3} \alpha+ \\
& \alpha_{4} X_{4}+e \ldots \ldots(1) \\
& Y=\alpha+\alpha_{1} X_{1}+\alpha_{2} X_{2}+\alpha_{3} X_{3}+\alpha_{4} X_{4} \\
& +\alpha_{5} Z_{0}+\alpha_{6} Z_{m}+e \ldots \ldots \ldots \ldots(2) \\
& \text { Keterangan: } \\
& Y \quad=\text { Nilai Perusahaan }
\end{aligned}
$$

NIAGAWAN Vol 8 No 3 November 2019

$$
\begin{aligned}
& \mathrm{X}_{1}=\text { Tata kelola } \\
& \text { perusahaan } \\
& \mathrm{X}_{2} \quad=\text { Kinerja lingkungan } \\
& \mathrm{X}_{3} \quad=\text { Struktur Modal } \\
& \mathrm{X}_{4} \quad=\text { Kualitas audit } \\
& \mathrm{Z}_{0} \quad=\text { Profitabilitas } \\
& \mathrm{Z}_{\mathrm{m}} \quad=\text { Moderating profitabilitas } \\
& \text { atas X1, X2, X3, dan X4 } \\
& \mathrm{a}_{0} \quad=\text { konstanta } \\
& \mathrm{a}_{1}-\mathrm{a}_{6}=\text { koefisien regresi } \\
& \varepsilon=\text { Pengaruh variabel lain } \\
& \text { (epsilon) atau residual (error }
\end{aligned}
$$

2. Uji asumsi klasik yang dilakukan yaitu uji normalitas, uji multikolinearitas, dan uji heteroskedastisitas.

3. Uji hipotesis menggunakan uji $\mathrm{t}$ (parsial) dan uji F (simultan)

4. Pengujian variabel moderating menggunakan uji residual..

\section{HASIL DAN PEMBAHASAN}

Statistik deskriptif memberikan gambaran mengenai karakteristik variabel penelitian yang diamati. Berikut tabel statistik deskriptif perusahaan sampel.

Tabel 1

Statistik Deskriptif

Descriptive Statistics

\begin{tabular}{|l|r|r|r|r|r|}
\hline & $\mathrm{N}$ & $\begin{array}{c}\text { Minim } \\
\text { um }\end{array}$ & $\begin{array}{c}\text { Maxim } \\
\text { um }\end{array}$ & $\begin{array}{c}\text { Mea } \\
\mathrm{n}\end{array}$ & $\begin{array}{c}\text { Std. } \\
\text { Deviati } \\
\text { on }\end{array}$ \\
\hline $\begin{array}{l}\text { Nilai } \\
\text { Perusahaa }\end{array}$ & 10 & .00 & .92 & .442 & .20915 \\
$\mathrm{n}$ & 5 & & & & \\
Kepemili & 10 & & & .590 & .22761 \\
kan & 5 & .00 & .99 & 6 & \\
Institusi & 10 & & & .376 & .10214 \\
Dewan & .14 & .75 & 1 & \\
Komisaris & 5 & & & & \\
Komite & 10 & & & 3.16 & .574 \\
Audit & 5 & 2 & & 1.29 & 1.7651 \\
Struktur & 10 & .00 & 11.68 & 80 & 6 \\
Modal & 5 & & & .072 & .08048 \\
Profitabili & 10 & .00 & .38 & 9 & \\
tas & 5 & .6 & & & \\
Valid N & 10 & & & & \\
(listwise) & 5 & & & \\
\hline
\end{tabular}

Dari tabel diatas dapat kita lihat nilai tertinggi, terendah dan rata-rata dari variabel nilai perusahaan, kepemilikan institusi, dewan komisaris, komite audit, struktur modal, dan profitabilitas perusahaan dengan jumlah perusahaan penelitian adsalah 105 perusahaan. 
Tabel berikut mendeskripsikan perbandingan jumlah penggunaan kantor auditor yang berafiliasi dengan big4 dan nonbig4.

Tabel 2

Statistik Frekuentif Kualitas Auditor Kualitas Audit

\begin{tabular}{|r|r|r|r|r|}
\hline & $\begin{array}{c}\text { Frequen } \\
\text { cy }\end{array}$ & $\begin{array}{c}\text { Perce } \\
\text { nt }\end{array}$ & $\begin{array}{c}\text { Valid } \\
\text { Perce } \\
\text { nt }\end{array}$ & $\begin{array}{c}\text { Cumulati } \\
\text { ve } \\
\text { Percent }\end{array}$ \\
\hline $\begin{array}{l}\text { non } \\
\text { big } \\
4\end{array}$ & 63 & 60.0 & 60.0 & 60.0 \\
$\begin{array}{l}\text { Vali } \\
\text { d big } \\
4\end{array}$ \\
$\begin{array}{l}\text { Tot } \\
\text { al }\end{array}$
\end{tabular}

dilihat kinerja perusahaan dalam hal pertanggungjawaban terhadap lingkungan berdasarkan Peraturan Kementerian Lingkungan Hidup dan Kehutanan RI No. 180 Tahun 2014 Tentang Hasil Penilaian Peringkat Kinerja Perusahaan dalam Pengelolaan Lingkungan Hidup Tahun 2013-2014.

Tabel 3

Deskriptif Frekuentif Kinerja Lingkungan

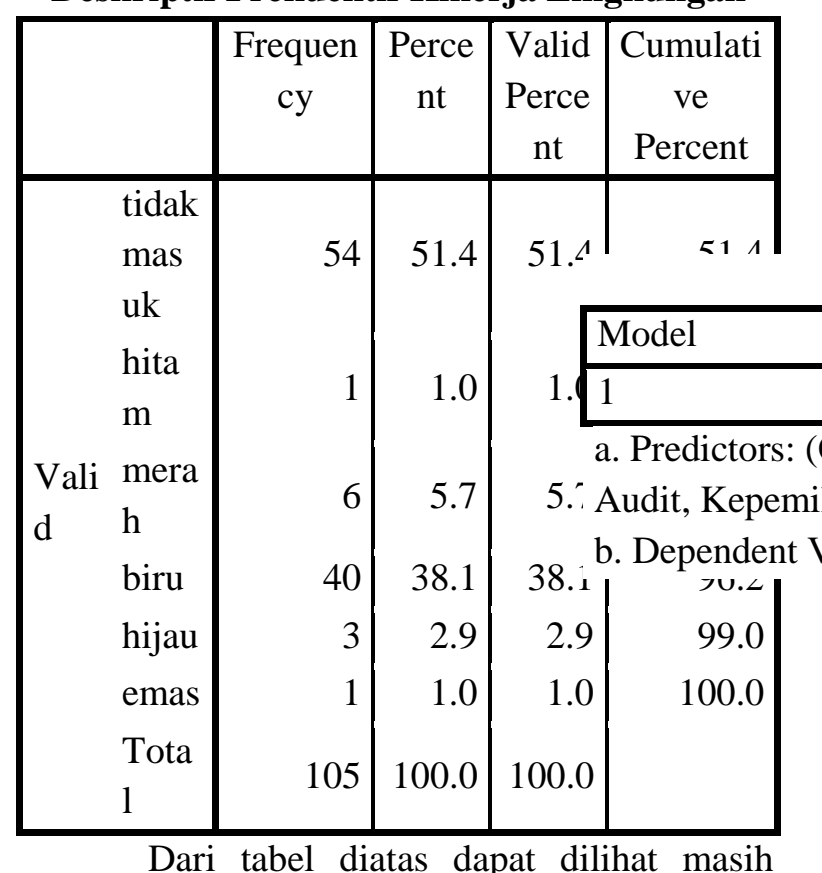

banyak perusahaan yang ikut dalam sampel penelitian yang belum masuk dalam pengamatan kinerja pengelolaan lingkungan hidup yaitu sekitar 51,4\%. Hal ini masih mengindikasikan kurangnya pengamatan pemerintah dalam memperhatikan dampak lingkungan dari aktivitas perusahaan dan perusahaan masih kurang bertanggung jawab terhadap kerusakan lingkungan yang dihasilkan. Ini juga berkaitan dengan keberlangsungan jangka panjang dari
NIAGAWAN Vol 8 No 3 November 2019 lingkungan dan masyarakat setempat. Oleh sebab itu, perlu perhatian lebih terhadap lingkungan perusahaan.

\section{Pengujian Asumsi Klasik}

\section{a. Uji Normalitas}

Pada Tabel 4 berikut ini dapat dilihat pengujian terhadap variabel-variabel yang digunakan dalam penelitian ini.

Tabel 4

Uji Normalitas Data

One-Sample Kolmogorov-Smirnov Test

\begin{tabular}{|ll|r|}
\hline & & $\begin{array}{c}\text { Unstandardized } \\
\text { Residual }\end{array}$ \\
\hline $\mathrm{N}$ & Mean & 105 \\
Normal & Std. & $0 \mathrm{E}-7$ \\
Parameters & \\
& Deviation & .13169061 \\
Most Extreme & Absolute & .126 \\
Differences & Positive & .095 \\
& Negative & -.126 \\
Kolmogorov-Smirnov Z & 1.294 \\
Asymp. Sig. (2-tailed) & .070 \\
\hline
\end{tabular}

a. Test distribution is Normal.

b. Calculated from data.

Dari data diatas dapat dilihat bahwa nilai signifikan diperoleh sebesar 0,070 atau lebih besar dari 0,05. Sehingga dapat disimpulkan data berdistribusi normal.

\section{b. Uji Autokorelasi}

Tabel 5

Uji Autokorelasi (Model Summary(b))

Model Summary ${ }^{\mathrm{b}}$ Durbin-Watson

Tabel 6

Uji Multikolinearitas (Coefficients(a)

Coefficients $^{\mathrm{a}}$

\begin{tabular}{|c|c|c|c|}
\hline \multirow{2}{*}{\multicolumn{2}{|c|}{ Model }} & \multicolumn{2}{|c|}{$\begin{array}{c}\text { Collinearity } \\
\text { Statistics }\end{array}$} \\
\hline & & Tolerance & VIF \\
\hline \multirow{7}{*}{1} & (Constant) & & \\
\hline & $\begin{array}{l}\text { Kepemilikan } \\
\text { Institusi }\end{array}$ & .959 & 1.042 \\
\hline & Dewan Komisaris & .995 & 1.005 \\
\hline & Komiter Audit & .985 & 1.015 \\
\hline & Kinerja & 878 & 1130 \\
\hline & Lingkungan & $.0 / 0$ & 1.159 \\
\hline & Struktur Modal & .970 & 1.031 \\
\hline
\end{tabular}




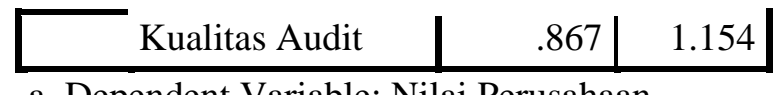

a. Dependent Variable: Nilai Perusahaan

\section{d. Uji Heteroskedastisitas}

Tabel 7

Uji Heteroskedastisitas (Coefficients(a)) Coefficients $^{\mathrm{a}}$

\begin{tabular}{|c|c|c|c|c|}
\hline \multirow[t]{2}{*}{ Model } & \multicolumn{2}{|c|}{$\begin{array}{l}\text { Unstandardized } \\
\text { Coefficients }\end{array}$} & \multirow[t]{2}{*}{$\mathrm{t}$} & \multirow[t]{2}{*}{ Sig. } \\
\hline & B & $\begin{array}{l}\text { Std. } \\
\text { Error }\end{array}$ & & \\
\hline (Constant) & .220 & .084 & 2.607 & .011 \\
\hline Kepemilikan & -.055 & .052 & 1070 & .286 \\
\hline Dewan & & & 1.012 & \\
\hline Komisaris & -.072 & .115 & -.626 & .532 \\
\hline Komiter & 001 & חרת & 066 & 048 \\
\hline Audit & .001 & $.0 \angle 0$ & .000 & .940 \\
\hline $\begin{array}{l}\text { Kinerja } \\
\text { Lingkungan }\end{array}$ & .007 & .008 & .854 & .395 \\
\hline $\begin{array}{l}\text { Struktur } \\
\text { Modal }\end{array}$ & $\begin{array}{r}6.475 \mathrm{E}- \\
005\end{array}$ & .000 & 1.472 & .144 \\
\hline $\begin{array}{l}\text { Kualitas } \\
\text { Audit }\end{array}$ & -.022 & .026 & -.872 & .385 \\
\hline
\end{tabular}

a. Dependent Variable: absu

Berdasarkan hasil yang diperoleh, seperti tampak pada tabel 5.7 di atas dapat dilihat bahwa tingkat signifikansi masingmasing variabel lebih dari $5 \%$ atau 0,05. Maka dapat disimpulkan bahwa asumsi heteroskedastisitas dapat ditolak.

\section{Pembahasan}

\section{Hasil Uji t}

Pada Tabel 8 diketahui hasil uji $t$ sebagai berikut

Table 8

Hasil Uji Statistik t

\begin{tabular}{|c|c|c|c|c|}
\hline \multirow[t]{2}{*}{ Model } & \multicolumn{2}{|c|}{$\begin{array}{c}\text { Unstandardized } \\
\text { Coefficients }\end{array}$} & \multirow[t]{2}{*}{$\mathrm{T}$} & \multirow[t]{2}{*}{ Sig. } \\
\hline & B & $\begin{array}{l}\text { Std. } \\
\text { Error }\end{array}$ & & \\
\hline (Constant) & .294 & .097 & 3.021 & .003 \\
\hline $\begin{array}{l}\text { Kepemilikan } \\
\text { Institusi }\end{array}$ & .015 & .060 & .260 & .796 \\
\hline $\begin{array}{l}1 \text { Dewan } \\
\text { Komisaris }\end{array}$ & -.014 & .131 & -.110 & .912 \\
\hline $\begin{array}{l}\text { Komite } \\
\text { Audit }\end{array}$ & .009 & .023 & .399 & .690 \\
\hline
\end{tabular}

NIAGAWAN Vol 8 No 3 November 2019

\begin{tabular}{l|r|r|r|r|} 
Kinerja & - & & & \\
Lingkungan & $2.995 \mathrm{E}-$ & .009 & -.003 & .997 \\
005 & & & \\
$\begin{array}{l}\text { Struktur } \\
\text { Modal }\end{array}$ & -.000 & .000 & -2.225 & .028 \\
$\begin{array}{l}\text { Kualitas } \\
\text { Audit }\end{array}$ & -.012 & .029 & -.417 & .678 \\
\hline
\end{tabular}

Dari tabel diatas dapat diperoleh model penelitian sebagai berikut:

$$
\begin{gathered}
\mathrm{Y}=0.294+0,15 \mathrm{X} 11-0,014 \mathrm{X} 12+0,09 \mathrm{X} 13- \\
2.995 \mathrm{E}-005 \mathrm{X} 2-0.00017 \mathrm{X} 3-0,012 \mathrm{X} 4
\end{gathered}
$$

Berdasarkan pengujian hipotesis yaitu uji $t$ hanya variabel struktur modal yang menunjukkan pengaruhnya terhadap nilai perusahaan pada perusahaan industri yang listing di Bursa Efek Indonesia. Hasil ini dapat dilihat dari tingkat signifikan sebesar 0.028 dimana lebih kecil dari 0,05. Sedangkan variabel kepemilikan tata kelola perusahaan (kepemilikan institusi, dewan komisaris, komite audit) kinerja lingkungan, dan kualitas audit berpengaruh tidak signifikan terhadap nilai perusahaan pada perusahaan industri di Bursa Efek Indonesia Periode 2014.

Hasil Uji F

Hasil uji statistik F menunjukkan semua variabel independen (tata kelola perusahaan, kinerja lingkungan, struktur modal, dan kualitas audit) secara simultan berpengaruh signifikan terhadap nilai parusahaan. Pada Tabel 9. dapat dilihat nilai $F_{\text {hitung }}$ sebesar 24,864 dengan tingkat signifikan sebesar 0.000 .

Tabel .9

Hasil Uji Statistik F

\begin{tabular}{|c|c|c|c|}
\hline \multicolumn{2}{|c|}{ Model } & $\mathrm{F}$ & Sig. \\
\hline \multirow{3}{*}{1} & Regression & 24.864 & $.000^{\mathrm{b}}$ \\
\hline & Residual & & \\
\hline & Total & & \\
\hline
\end{tabular}
ANOVA $^{\mathrm{a}}$

a. Dependent Variable: Nilai Perusahaan

b. Predictors: (Constant), Kualitas Audit, Struktur Modal, Dewan Komisaris, Komiter Audit, Kepemilikan Institusi, Kinerja Lingkungan

Dari hasil tersebut dapat disimpulkan bahwa tata kelola perusahaan (kepemilikan institusi, dewan komisaris, komite audir), kinerja lingkungan, struktur modal, dan kualitas audit berpengaruh signifikan terhadap nilai perusahaan pada perusahaan industry yang listing di Bursa Efek Indonesia periode 2014. 


\section{Uji Residual}

Uji residual untuk melihat apakah variabel moderating dalam model penelitian tersebut dapat dijadikan sebagai variabel moderating. Pengujian variabel moderating dapat dilihat sebagai berikut:

Tabel 10

Uji Residual Variabel Profitabilitas

\begin{tabular}{|l|c|c|}
\hline Model & $\mathrm{t}$ & Sig. \\
\hline $\begin{array}{l}\text { (Constant) } \\
1\end{array}$ & 5.198 & .000 \\
$\begin{array}{l}\text { Nilai } \\
\text { Perusahaan }\end{array}$ & -.598 & .551 \\
\hline
\end{tabular}

a. Dependent Variable:

absres_1

Dari hasil uji residual diatas tampak bahwa nilai $\mathrm{t}$ sebesar -0.598 dengan tingkat signifikan sebesar 0.551 sehingga dapat disimpulkan bahwa variabel profitabilitas tidak dapat dijadikan sebagai variabel moderating pada penelitian ini. Sedangkan syarat suatu variabel dapat dijadikan sebagai variabel moderating menurut Ghozali (2015) variabel tersebut memiliki nilai t negatif dengan tingkat signifikan lebih kecil dari 5\%.

\section{Pembahasan Hasil Penelitian}

Pengaruh Tata Kelola Perusahaan Terhadap Nilai Perusahan

Vaiabel tata kelola perusahaan diproksikan pada kepemilikan institusi, dewan komisaris, dan komite audit. Pada variabel ini menunjukkan adanya pengawasan terhadap pelaksanaan kegiatan perusahaan sehingga perusahaan berjalan dengan apa yang sudah direncanakan. Pada pengujian vaiabel ini mempeoleh hasil bahwa tata kelola perusahaan yang diproksikan pada kepemilikan institusi, dewan komisaris, dan komite audit menunjukkan berpengaruh yang tidak signifikan terhadap nilai perusahaan. Sehingga dapat disimpulkan bahwa hipotesis ditolak. Hal ini mengindikasikan bahwa adanya pengawasan untuk pelaksanaan tata kelola perusahaan yang baik tidak mempengaruhi nilai dari sebuah perusahaan, dan terdapat kepentingan yang tujuannya untuk menguntungkan pihak-pihak yang berkepentingan dengan adanya nilai perusahaan yang meningkat. Investor dalam hal melihat nilai perusahaan masih mengindikasikan keuntungan jangka pendek yang akan diperoleh apabila nilai perusahaan meningkat. Penelitian ini bertolak belakang dengan penelitian yang dilakukan
NIAGAWAN Vol 8 No 3 November 2019 Hariati dan Widya (2014) dan Kristie dan Robin (2016) yang menunjukkan bahwa tata kelola perusahaan berpengaruh terhadap nilai perusahaan.

\section{Pengaruh Kinerja Lingkungan Terhadap Nilai Perusahaan.}

Kinerja lingkungan menunjukkan bagaimana tanggung jawab suatu perusahaan terhadap lingkungan yang rusak akibat dari aktivitas operasi yang dilakukannya berdasarkan penilaian dari Peraturan Kementerian Lingkungan Hidup dan Kehutanan RI No. 180 Tahun 2014 Tentang Hasil Penilaian Peringkat Kinerja Perusahaan dalam Pengelolaan Lingkungan Hidup Tahun 2013-2014.. Dari hasil pengujian hipotesis diperoleh bahwa kinerja lingkungan berpengaruh tidak signifikan terhadap nilai perusahaan. Hal ini menunjukkan indikasi bahwa investor masih melihat bahwa perusahaan yang mengeluarkan dananya untuk lingkungan dianggap tidak akan meningkatkan keuntungannya dimasa depan dan masih dianggap sebagai beban yang tidak menguntungkan. Sehingga investor masih belum menganggap adanya kinerja lingkungan yang dikeluarkan Kementrian Lingkungan Hidup dan Kehutanan tidak akan meningkatkan keuntungan perusahaan yang berdampak terhadap return investor kedepan. Penelitian ini bertentangan dengan penelitian yang dilakukan oleh Hariati dan Widya (2014) yang menunjukkan hasil bahwa kinerja lingkungan berpengaruh terhadap nilai perusahaan sehingga pada penelitian ini hipotesis ditolak. Tetapi sejalan dengan penelitian yang dilakukan Mazda (2013).

\section{Pengaruh Struktur Modal Terhadap Nilai Perusahaan}

Struktur modal menunjukkan jumlah hutang yang digunakan perusahaan untuk membiayai aktivitas operasi perusahaan termasuk didalamnya membeli aset perusahaan. Pada penelitian ini menunjukkan hasil bahwa struktur modal berpengaruh negative signifikan terhadap nilai perusahaan sehingga hipotesis diterima. Penelitian ini bertentangan dengan penelitian yang dilakukan oleh Meythi, dkk (2012) yang menunjukkan struktur modal berpengaruh tidak signifikan terhadap nilai perusahaan tetapi sejalan dengan penelitian Rahman (2014). Dari hasil ini menunjukkan bahwa investor mempertimbangkan hutang yang dimiliki perusahaan dalam menanamkan 
modalnya diperusahaan dimana hutang tersebut berkaitan dengan bunga yang dibayarkan sehingga akan berdampak terhadap pengembalian atas modal yang ditanamkan investor perusahaan. Semakin besar hutang perusahaan maka semakin besar pula bunga yang akan dibayarkan beserta pokoknya sehingga semakin berisiko. Dari hasil uji hipotesis menunjukkan berpengaruh negatif sehingga dapat disimpulkan bahwa semakin besar hutang perusahaan semakin kurang minat invesitor untuk menanamkan modalnya diperusahaan sehingga nilai perusahaan semakin kecil.

\section{Pengaruh Kualitas Audit Terhadap Nilai Perusahaan}

Variabel kualitas audit menunjukkan kualitas audit laporan keuangan yang dilakukan oleh kantor akuntan public yang dilakukan KAP yang berafiliasi dengan big4 dengan KAP yang tidak berafiliasi dengan big4. Hasil pengujian menunjukkan bahwa kualitas audit suatu KAP baik yang berafiliasi dengan big4 dengan yang tidak berafiliasi dengan big4 berpengaruh tidak signifikan terhadap nilai perusahaan. hal ini menunjukkan bahwa investor tidak menjadikan suatu informasi keuangan baik yang diaudit oleh KAP big4 dengan KAP non big4 sebagai informasi yang menguntungkan bagi pengembalian modal mereka. Investor masih menganggap bahwa informasi keuangan tersebut sebagai pendukung bukan sebagai yang mempengaruhi mereka untuk membuat keputusan menginvestasikan modal mereka ke perusahaan sehingga nilai perusahaan meningkat. Investor juga menganggap dengan menggunakan KAP big4 merupakan pengeluaran yang besar dikarenakan diaudit oleh KAP Big4 menggunakan dana yang cukup besar sehingga akan berdampak terhadap return yang akan mereka peroleh. Hasil penelitian ini sejalan dengan penelitian yang dilakukan oleh Putra (2009) dan Cahaya (2012) yang menunjukkan bahwa kualitas audit berpengaruh tidak signifikan terhadap nilai perusahaan.

\section{Pengaruh Tata Kelola Perusahaan, Kinerja Lingkungan, Struktur Modal Dan Kualitas Audit Berpengaruh Terhadap Nilai Perusahaan Dengan Profitabilitas Sebagai Variabel Moderating}

Pengujian hipotesis yang berikutnya yaitu menguji secara bersama-sama variabel tata
NIAGAWAN Vol 8 No 3 November 2019 kelola perusahaan, kinerja lingkungan, struktur modal, dan kualitas audit terhadap nilai perusahaan dengan profitabilitas sebagai variabel moderating. Hasil pengujian tersebut menunjukkan bahwa secara bersama-sama variabel tersebut berpengaruh terhadap nilai perusahaan. Tetapi profitabilitas tidak dapat dijadikan sebagai variabel moderating. Hal ini menunjukkan bahwa secara keseluruhannya bahwa nilai suatu perusahaan dipengaruhi oleh tata kelola perusahaan, kinerja lingkungan struktur modal, dan kualitas audit dengan pandangan yang berbeda-beda setiap investor sehingga terdapat pengaruh yang besar dalam mempengaruhi nilai perusahaan dan ada yang tidak signifikan mempengaruhi nilai perusahaan. Sedangkan profitabilitas tidak bisa dijadikan sebagai variabel pengganggu variabel independen dalam mempengaruhi variabel dependen.

\section{KESIMPULAN DAN SARAN}

Dari hasil penelitian dapat ditarik kesimpulan bahwa secara parsial hanya variabel struktu modal yang berpengaruh signifikan terhadap nilai perusahaan. Sehingga tampak bahwa semakin besar hutang perusahaan yang digunakan untuk membiayai aktivitas operasi maka semakin kecil pula nilai perusahaan. Sedangkan secara umum tata kelola perusahaan, kinerja lingkungan, struktur modal, kualitas auditor berpengaruh secara simultan terhadap nilai perusahaan.

Berdasarkan kesimpulan diatas hanya variabel struktur modal yang berpengaruh terhadap nilai perusahaan. Oleh sebab itu, perlu dilakukan penelitian lebih mendalam mengenai faktor yang mempengaruhi nilai perusahaan. Hal ini berkaitan dengan ketertarikan investor maupun kreditor dalam menanamkan modalnya diperusahaan dan perusahaan tetap dapat menjalankan aktivitasnya. Disamping itu, pada penelitian selanjutnya lebih memperluas sektor perusahaan yang bertujuan mengetahui faktor yang mempengaruhi nilai perusahaan pada setiap sektor..

\section{REFERENSI}

Cahaya, Nugrahani. 2012. Pengaruh Kualitas Audir Terhadap Nilai Perusahaan (Manajemen Laba Sebagai Variabel Moderating). Skripsi Fakultas Ekonomi Universitas Sebelas Maret. Surakarta. 
Ghozali, Imam. .2015. Aplikasi Analisis Multivariate dengan Program SPSS. Semarang: Badan Penerbit Universitas Diponegoro.

Hariati, Isnin, dan Widya, Yeney. 2014. Pengaruh Tata Kelola Perusahaan Dan Kinerja Lingkungan Terhadap Nilai Perusahaan. Artikel skripsi S1 Jurusan Akuntansi, FEB, Universitas Brawijaya Keputusan Menteri Lingkungan Hidup dan Kehutanan Republik Indonesia. No. 180 Tahun 2014 Tentang Hasil Penilaian Peringkat Kinerja Perusahaan Dalam Pengelolaan Lingkungan Hidup Tahun 2013-2014

Kristie. Onasis, dan Robin. 2016. Pengaruh Tata

Kelola Perusahaan Terhadap Nilai Perusahaan Pada Perusahaan Sektor Keuangan Yang Terdaftar di Bursa Efek Indonesia. Jurnal Bina Ekonomi Vol 20 No 1

Mazda, Eko. 2013. Pengaruh Kinerja Lingkungan Terhadap Nilai Perusahaan dan Kinerja Keuangan. Jurnal Ekonomi.Vol 4 No. 1 Mei 2013

Meythi. Martusa, Riki,. dan Debbianita. 2012. Pengaruh Struktur Modal Terhadap Nilai Perusahaan Dengan Pertumbuhan Perusahaan Sebagai Variabel Moderating. Hibah Penelitian Program Pendidikan Profesi Akuntansi Universitas Kristen Maranatha Bandung.

Putra, Asmanda, Bintang. 2009. Pengaruh Kualitas Audit Terhadap Nilai Perusahaan Dengan Manajemen Laba Sebagai Variabel Intervening Di Industri Perbankan Indonesia. Skripsi Fakultas Ekonomi Universitas Sebelas Maret Surakarta

Rahman, Rusdi, Hamidi (2014). Pengaruh Struktur Modal Terhadap Nilai Perusahaan Dengan Profitabilitas Sebagai Variabel Intervening Pada Perusahaan Properti dan Real Estate Di Bursa Efek Indonesia. Tesis Program Magister. Program Studi Manajemen. Program Pascasarjana Universitas Udayana. Denpasar

http://www.kompasiana.com/chitaniasari/tahunini-indonesia-tak-kebagian-laba-freeportrapor-merah-dahlaniskan 54f7955da33311707a8b4697
NIAGAWAN Vol 8 No 3 November 2019 http://www.kompasiana.com/bobobladi/kebobro kan-freeport-pencemaran-lingkunganpelanggaran-ham-perusaan-emas-terbesardiindonesia 5519c8bca33311a61bb6595c http://finance.laws.com/enron-scandal-summary 